
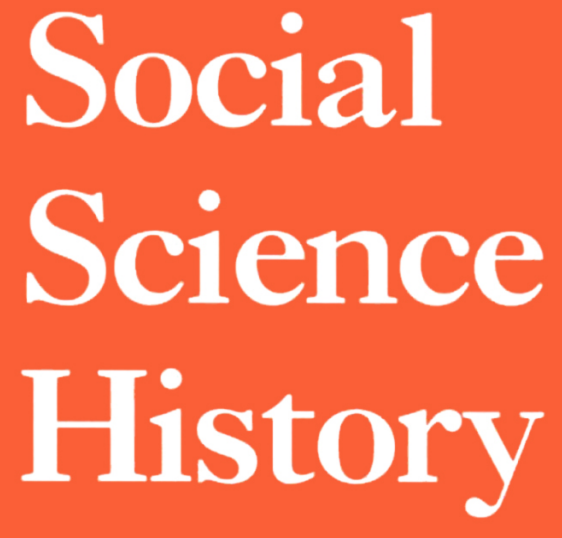

Volume 30

Number 1

Spring 2006

The official journal of

the Social Science

History Association

Presidential Address

Mary Jo Maynes

Unthinking Teleologies: Markets, Theories, Histories

William J. Collins

The Political Economy of State Fair Housing Laws before 1968

Randall Strahan, Matthew Gunning, and Richard L. Vining Jr.

From Moderator to Leader:

Floor Participation by U.S. House Speakers, 1789-1841

Joanna Short

Confederate Veteran Pensions, Occupation, and Men's Retirement in the New South

Robert Barde and Gustavo J. Bobonis

Detention at Angel Island: First Empirical Evidence

Adam D. Sheingate and Takakazu Yamagishi

Occupation Politics: American Interests and the Struggle over Health Insurance in Postwar Japan 
Executive Editorial Committee

Katherine A. Lynch, History, Carnegie Mellon University, Editor

Kathleen Blee, Sociology, University of Pittsburgh

Wendy Z. Goldman, History, Carnegie Mellon University

William Keech, Political Science, Carnegie Mellon University

Richard Maddox, Anthropology, Carnegie Mellon University

John E. Murray, Economics, University of Toledo

Joe W. Trotter, History, Carnegie Mellon University

\section{Postdoctoral Editors}

Jason D. Martinek, History, Carnegie Mellon University

Connie G. Oxford, Sociology, University of Pittsburgh

\section{Graduate Student Editors}

Deirdre Clemente, History, Carnegie Mellon University

Andrew Lotz, Political Science, University of Pittsburgh

\section{Editorial Board}

John Aldrich, Political Science, Duke University

Douglas L. Anderton, Sociology, University of Massachusetts-Amherst

Jörg Baten, Economic History, University of Tübingen

William J. Collins, Economics, Vanderbilt University

Donna R. Gabaccia, History, University of Minnesota

Ian Gregory, Geography, Queen's University Belfast

Michael Haines, Economics, Colgate University

Alice Bee Kasakoff, Anthropology, University of South Carolina

Ira Katznelson, Political Science, Columbia University

David Kertzer, Anthropology, Brown University

James Z. Lee, History, University of Michigan

David W. Miller, History, Carnegie Mellon University

Richard Oestreicher, History, University of Pittsburgh

Steven Ruggles, History, University of Minnesota

Theda Skocpol, Political Science, Harvard University

Frans van Poppel, Demography, Netherlands Interdisciplinary

Demographic Institute

\section{SSHA Executive Director}

Erik Austin, Institute for Social Research, University of Michigan

Graduate Editorial Assistant

Shera A. Moxley, History and Policy, Carnegie Mellon University

The Social Science History Association, the editors, and the publisher of Social Science History gratefully acknowledge Carnegie Mellon University's support of the journal. 
Social

Science

History
Volume 30

Number 1

Spring 2006

The official journal of the Social Science

History Association 
Social Science History seeks to advance the study of the past by publishing research that appeals to its interdisciplinary readership of historians, sociologists, cconomists, political scientists, anthropologists, and geographers. The journal invites articles that blend empirical research with theoretical work, undertake comparisons across time and space, or contribute to the development of quantitative and qualitative methods of analysis.

As the official journal of the Social Science History Association, Social Science History reflects the interests of members who are active in the Association's research networks. However, it also welcomes submissions from the larger international research community of social scientists.

For information about the Association's activities, its research networks, and its annual conference, please see its Web site at www.ssha.org/index.shtml

Manuscripts (four copies) should be sent to Social Science History, Department of History, Carnegie Mellon University, Baker Hall 240, Pittsburgh, PA 15213-3890. All submissions must be typed with all written material double-spaced (including quotations, notes, information in tables, and the list of references) using only one side of the paper. A word count should be included on the title page. Typewritten lines should not exceed five and one-half inches in length. Brief parenthetical citations are included in the text; all complete references are listed alphabetically at the end of the article; and notes are used only for discursive comments and appear immediately before the list of references. For detailed information on this journal's style, contributors should refer to the Social Science History "Style Guide for Authors," which may be downloaded in PDF format from our Web site at www.history.cmu.edu/ssh-journal or requested via e-mail at ssh-journal@andrew.cmu.edu. The Social Science History Association does not accept responsibility for statements of fact or opinion made by the contributors.

Social Science History (ISSN 0145-5532) is published quarterly, at $\$ 117$ for (print-plus-electronic) institutions and libraries, $\$ 60$ for individuals, and $\$ 15$ for students, for the Social Science History Association by Duke University Press, 905 W. Main St., Suite 18B, Durham, NC 27701. Periodicals postage paid at Durham, NC, and additional mailing offices. Postmaster: Send address changes to Social Science History, Box 90660, Duke University Press, Durham, NC 27708-0660. 


\section{Presidential Address}

Unthinking Teleologies: Markets, Theories, Histories

Mary Jo Maynes

1

\section{Articles}

The Political Economy of State Fair Housing Laws before 1968

William J. Collins

15

From Moderator to Leader: Floor Participation by U.S. House Speakers, 1789-1841

Randall Strahan, Matthew Gunning, and Richard L. Vining Jr. 51

Confederate Veteran Pensions, Occupation, and Men's Retirement in the New South

Joanna Short

75

Detention at Angel Island: First Empirical Evidence

Robert Barde and Gustavo J. Bobonis

103

Occupation Politics: American Interests and the Struggle over Health Insurance in Postwar Japan

Adam D. Sheingate and Takakazu Yamagishi

137

Contributors

165 